\title{
PENINGKATAN MOTIVASI DAN PRESTASI BELAJAR MATA KULIAH MATEMATIKA 3 MAHASISWA PGSD UNIVERSITAS PGRI YOGYAKARTA MELALUI COOPERATIVE LEARNING TIPE JIGSAW
}

\section{Danuri}

PGSD Universitas PGRI Yogyakarta

danuri@upy.ac.id

\section{Informasi artikel}

Sejarah artikel

Diterima $\quad: 20 / 10$

Revisi : I4

Dipublikasikan : 28/12/2107

Kata kunci:

motivasi,

prestasi,

cooperative learning tipe Jigsaw

\begin{abstract}
ABSTRAK
Tujuan dari penelitian ini adalah mengetahui peningkatan motivasi dan prestasi belajar mata kuliah matematika 3 Mahasiswa PGSD Universitas PGRI Yogyakarta melalui implementasi cooperative learning tipe Jigsaw.

Jenis penelitian ini adalah Penelitian Tindakan Kelas (PTK) Objek penelitian ini adalah keseluruhan proses implementasi cooperative learning tipe jigsaw. Desain penelitian menggunakan model spiral Kemmis dan Mc Taggart yang terdiri dari 4 langkah yaitu perencanaan (planning), tindakan (acting), pengamatan (observing), dan refleksi (reflecting). Data dalam penelitian ini diperoleh dari hasil observasi, hasil tes, hasil angket partisipasi belajar siswa, hasil wawancara, dan dokumentasi. Data yang diperoleh dianalisis melalui tahapan: pengumpulan data, reduksi data, display data, dan penarikan kesimpulan.

Hasil penelitian menunjukkan bahwa setelah diterapkan cooperative learning tipe Jigsaw adalah sebagai berikut: Prestasi dan motivasi belajar mahasiswa mengalami peningkatan setelah menerapkan model pembelajaran cooperative learning dengan tipe jigsaw pada materi bangun ruang. Hal ini ditunjukan dengan skor rerata kelas yang mengalami peningkatan pada tiap siklusnya. Pada prestasi belajar peningkatan yang terjadi 36,96 pada kondisi awal, 57,92 pada siklus I dan 74,28 pada siklus II. Sedangkan peningkatan motivasi belajar 44,86 pada kondisi awal, 65,64 pada siklus I, dan 77,33 pada siklus II.
\end{abstract}

\section{ABSTRACT}

Key word:

motivation,

achievement,

cooperative learning type Jigsaw

\begin{abstract}
The purpose of this research is to know the improvement of motivation and learning achievement of mathematics course 3 PGSD Students of PGRI University Yogyakarta through implementation of cooperative learning Jigsaw type.

The type of this research is Classroom Action Research (CAR) The object of this research is the whole process of implementation of cooperative learning type jigsaw. The research design uses spiral model Kemmis and Mc Taggart consisting of 4 steps that are planning (planning), action (acting), observation (observing), and reflection (reflecting). The data in this research is obtained from the observation, the test result, the result of questionnaire of student learning participation, interview result, and documentation. The data obtained are analyzed through stages: data collection, data reduction, data display, and conclusion.

Student achievement and motivation have improved after applying cooperative learning jigsaw type on building material. This is indicated by the average grade scores that increase in each cycle. On learning achievement of the increase that occurred 36,96 at initial condition, 57,92 in cycle I and 74,28 in cycle II. Whereas the increase of learning motivation 44,86 at initial condition, 65,64 in cycle I, and 77,33 in cycle II.
\end{abstract}

\section{Pendahuluan}

Pendidikan Indonesia telah merancang berbagai cara serta merumuskan tujuan pendidikan nasional sehingga sesuai dengan kebutuhan pada zaman ini. Berdasarkan Undang-undang Nomor 20 tahun 2003 tentang Sistem 
Pendidikan Nasional pasal 3, tujuan pendidikan nasional adalah mengembangkan potensi peserta didik agar menjadi manusia yang beriman dan bertakwa kepada Tuhan Yang Maha Esa, berakhlak mulia, sehat, berilmu, cakap, kreatif, mandiri, dan menjadi warga negara yang demokratis serta bertanggung jawab.

Berkaitan dengan usaha mencapai tujuan pendidikan nasional tersebut, maka kita sebagai warga negara hendaknya turut serta menyukseskan program pendidikan yang dirancang pemerintah yaitu dengan melibatkan diri secara aktif dalam membangun pendidikan Indonesia. Dalam upaya tersebut kegiatan belajar mengajar menjadi aspek utama dalam mencapai hasil belajar yang diinginkan.

Melalui standar tersebut, mahasiswa diharapkan mampu menyelesaikan berbagai tuntutan yang ada sehingga dapat mencapai kompetensi yang baik. Pada mata kuliah matematika seringkali mahasiswa mengalami kesulitan belajar yang mengakibatkan prestasi belajar yang rendah. Prestasi belajar yang dirasa kurang memuaskan tersebut menyebabkan kurangnya motivasi belajar mahasiswa pada mata kuliah matematika. Motivasi sangat penting guna meningkatkan kemauan seseorang untuk melakukan sesuatu, begitu pula peran motivasi belajar. Tanpa diimbangi dengan motivasi belajar yang tinggi maka kegiatan pembelajaran akan berjalan kurang baik.

Melalui hasil observasi yang dilakukan pada tanggal I3 Oktober 2016 pada mahasiswa Matematika 3 Program Studi PGSD Universitas PGRI Yogyakarta kelas AI, dimana nampak dari kurangnya kerja sama antara mahasiswa dalam menyelesaikan masalah, terdapat lebih dari 50\% mahasiswa tidak peduli terhadap presentasi yang dilakukan mahasiswa lain di kelas, variasi media pembelajaran yang digunakan di dalam kelas masih terbatas pada layar LCD dan penggunaan microsoft powerpoint, Selain observasi yang telah dilakukan, peneliti juga melalukan studi dokumen terkait prestasi belajar siswa. Melalui studi dokumen yang telah dilakukan diperoleh hasil diperoleh hasil $>50 \%$ mahasiswa memiliki nilai dibawah KKM.

Berdasarkan beberapa permasalah yang muncul di kelas, dapat diindikasi bahwa motivasi belajar mahasiswa masih rendah nampak dari perilaku mahasiswa ketika dikelas selama mengikuti kegiatan perkuliahan. Motivasi belajar merupakan suatu dorongan yang menggerakkan seseorang untuk belajar atau menguasai materi yang sedang diikutinya dalam proses pembelajaran, dimana mengarahkan perilaku mereka untuk mencapai tujuan tertentu. Pada penelitian tindakan kelas ini peneliti menawarkan solusi terkait motivasi belajar dan prestasi belajar mahasiswa yang masih belum memenuhi target, yaitu menggunakan model pembelajaran kooperatif (cooperative learning) dengan metode Jigsaw.

Berdasarkan rumusan masalah yang telah dikemukakan, tujuan penelitian ini adalah:

I. Mengetahui penerapan model pembelajaran kooperatif dengan metode jigsaw dapat meningkatkan motivasi belajar mahasiswa kelas AI PGSD Universitas PGRI Yogyakarta tahun ajaran 20I6/2017.

2. Mengetahui apakah penerapan model pembelajaran kooperatif dengan metode jigsaw dapat meningkatkan motivasi belajar mahasiswa kelas AI PGSD Universitas PGRI Yogyakarta tahun ajaran 20I6/20I7.

3. Mengetahui apakah penerapan model pembelajaran kooperatif dengan metode jigsaw dapat meningkatkan prestasi belajar mahasiswa kelas AI PGSD Universitas PGRI Yogyakarta tahun ajaran 2016/2017.

\section{TINJAUAN PUSTAKA}

\section{Motivasi}

Mc. Donald yang di kutip oleh Sardiman (2003: 198), motivasi adalah perubahan energi dalam diri seseorang yang ditandai dengan munculnya "feeling" dan didahului dengan tanggapan terhadap adanya tujuan. Dari pengertian yang dikemukakan Mc. Donald ini mengandung tiga elemen penting yaitu; (I) bahwa motivasi itu mengawali terjadinya perubahan energi pada diri setiap individu manusia, (2) motivasi ditandai dengan munculnya rasa dan afeksi seseorang, (3) motivasi akan dirangsang karena adanya tujuan. Oleh sebab itu motivasi sangat diperlukan dalam kegiatan belajar sehingga seseorang dapat bergerak dengan menunjukan perilaku positif menuju tujuan belajar yang diinginkanSetiap mata pelajaran yang dipelajari di sekolah mempunyai tujuan masingmasing yang hendak dicapai.

Berdasarkan definisi-definisi di atas, dapat ditarik kesimpulan bahwa pembelajaran matematika merupakan serangkaian aktivitas guru dalam memberikan pengajaran terhadap mahasiswa untuk membangun konsep-konsep dan prinsip-prinsip matematika dengan metode atau pendekatan mengajar dan aplikasinya agar dapat meningkatkan kompetensi dasar dan kemampuan mahasiswa. Tujuan dari pembelajaran matematika biasanya mengarah pada tiga kawasan taksonomi bloom, yaitu kognitif, afektif, dan psikomotorik. Motivasi dan belajar merupakan dua aspek yang tidak dapat dipisahkan. 
Motivasi dan belajar merupakan dua aspek yang tidak dapat dipisahkan. Winkel (2004:59) memaparkan bahwa belajar adalah suatu aktivitas mental atau psikis yang berlangsung dalam interaksi aktif dengan lingkungan yang menghasilkan sejumlah perubahan dalam pengetahuan, pamahaman, ketrampilan dan nilai sikap perubahan itu secara relatif, konstan dan berbekas. Sejalan dengan pendapat tersebut Suryabrata (2002:59) mengungkapkan bahwa belajar adalah suatu proses yang membawa perubahan dan dari perubahan itu di dapat kecakapan baru karena adanya suatu usaha yang sengaja. Tanpa adanya motivasi maka kegiatan belajar tidak dapat mencapai tujuan yang maksimal

Berdasarkan pendapat para ahli di atas maka dapat disimpulkan bahwa motivasi belajar merupakan dorongan yang muncul dalam diri seseorang untuk memperoleh pengetahuan baru dimana mempengaruhi perilakukanya. Terdapat beberapa indikator yang menunjukan motivasi belajar seseorang. Siswa yang memiliki motivasi yang kuat akan mempunyai sinergi yang banyak untuk melakukan kegiatan belajar. Menurut Muhaimin (200I: I38), seorang anak/ peserta didik dapat dikatakan memiliki motivasi apabila: (I) bersungguh-sungguh, menunjukkan minat, mempunyai perhatian, dan rasa ingin tahu yang kuat untuk ikut serta dalam kegiatan belajar; (2) berusaha keras dan memberikan waktu yang cukup untuk melakukan kegiatan tersebut; dan (3) terus bekerja sampai tugasnya selesai. Sejalan dengan pendapat tersebut, Sardiman (2007) berpendapat bahwa setiap orang yang memiliki motivasi mempunyai ciri, yaitu: (I) tekun menghadapi tugas; (2) ulet menghadapi kesulitan; (3) menunjukkan minat terhadap bermacam-macam masalah; (4) mandiri dalam belajar; (5) cepat bosan pada tugas yang rutin; (6) dapat mempertahankan pendapatnya; (7) tidak mudah melepaskan yang diyakininya, dan (8) senang memecahkan masalah.

\section{Prestasi Belajar}

Dalam bahasa Inggris kata prestasi adalah aachievement, namun kata tersebut berasal dari kata "to achieve" yang berarti mencapai, maka dapat kita artikan sebagai pencapaian atau apa yang dicapai. Menurut Sumadi Suryabrata (2006: 297), prestasi dapat pula didefinisikan sebagai berikut : "nilai merupakan perumusan terakhir yang dapat diberikan oleh guru mengenai kemajuan/prestasi belajar siswa selama masa tertentu". Jadi, prestasi adalah hasil usaha siswa selama masa tertentu melakukan kegiatan.

Dalam proses pendidikan prestasi dapat diartikan sebagai hasil dari proses belajar mengajar yakni, penguasaan, perubahan emosional, atau perubahan tingkah laku yang dapat diukur dengan tes tertentu (Abdullah, 2008) Untuk mengetahui prestasi belajar mahasiswa perlu diadakan suatu evaluasi yang bertujuan untuk mengetahui sejauh manakah proses belajar dan pembelajaran itu berlangsung secara efektif. Efektifitas proses belajar tersebut akan tampak pada kemampuan mahasiswa menguasai materi pelajaran.

\section{Model Cooperative Learning}

Model pembelajaran dapat dijadikan sebagai salah satu cara untuk meningkatkan kualitas pembelajaran di kelas. Model-model pembelajaran memiliki banyak variasi, salah satunya yaitu model Cooperative Learning. Menurut Rusman (20I I: 202) Cooperative Learning merupakan bentuk pembelajaran dengan cara siswa belajar dan bekerja dalam kelompok-kelompok kecil secara kolaboratif yang anggotanya terdiri dari 4 sampai 5 orang. Sejalan dengan pendapat Rusman, Slavin (dalam Isjoni 2007: I5) Cooperative Learning adalah suatu model pembelajaran dimana sistem belajar dan bekerja dalam kelompok kecil yang berjumlah 4-5 orang secara kolaboratif sehingga dapat merangsang siswa lebih bergairah dalam belajar. Komalasari (201 I: 62) menjelaskan bahwa Cooperative Learning adalah suatu strategi pembelajaran dimana siswa belajar dan bekerja dalam kelompok-kelompok kecil secara kolaboratif yang anggotanya terdiri dari 2 sampai 5 orang, dengan struktur kelompoknya yang bersifat heterogen.

Sedangkan menurut Johnson (dalam Isjoni, 2007: I5) mengemukakan,

"cooperanon means working together to accomplish shared goals. Within cooperative activities individuals seek outcomes that are beneficial to all other groups member cooperative learning is the intructional use of small groups that allows students to work together to maximize their own and each other as learning".

Berdasarkan uraian tersebut, maka Cooperative Learning mengandung arti bekerja bersama dalam mencapai tujuan bersama. Dalam kegiatan kooperatif siswa mencari hasil yang menguntungkan bagi seluruh anggota kelompok. Belajar kooperatif adalah pemanfaatan kelompok kecil untuk memaksimalkan belajar mereka dan belajar anggota lainnya dalam kelompok itu. Prosedur Cooperative Learning didesain untuk mengaktifkan siswa melalui inkuiri dan diskusi dalam kelompok kecil yang terdiri atas 4-6 orang. 


\section{Jigsaw}

Jigsaw pada hakikatnya melibatkan tugas yang memungkinkan siswa saling membantu dan mendukung satu sama lain dalam menyelesaikan tugas. Dalam model pembelajaran ini siswa akan memiliki persepsi yang sama, mempunyai tanggung jawab individual dan kelompok dalam mempelajari materi yang diberikan, saling membagi tugas dan tanggung jawab yang sama besarnya dalam kelompok, serta dapat belajar kepemimpinan

Dalam pelaksanaan pembelajaran kooperatif tipe jigsaw, kelas dibagi ke dalam beberapa kelompok yang terdiri dari kelompok asal dan kelompok ahli. Kelompok asal adalah kelompok induk siswa yang beranggotakan siswa dengan kemampuan asal yang berbeda. Kelompok ahli adalah kelompok siswa yang terdiri dari anggota kelompok asal yang berbeda yang ditugaskan untuk mempelajari dan mendalami topik tertentu dan menyelesaikan tugas-tugas yang berhubungan dengan topik untuk kemudian dijelaskan kepada kelompok asal.

Anggota dari kelompok asal yang berbeda bertemu dengan topik yang sama dalam kelompok ahli untuk berdiskusi dan membahas materi yang ditugaskan pada masing-masing anggota kelompok serta membantu satu sama lain untuk mempelajari topik tersebut. Setelah pembahasan selesai, para anggota kelompok kemudian kembali pada kelompok asal dan mengajarkan pada teman sekelompoknya apa yang telah mereka dapatkan pada saat di kelompok ahli.

\section{Metode Penelitian}

\section{Jenis Penelitian}

Jenis penelitian yang digunakan oleh peneliti adalah penelitian tindakan kelas. Penelitian tindakan kelas adalah suatu bentuk kajian yang bersifat reflektif oleh pelaku tindakan. Mulyasa (2008:I55) menyatakan bahwa penelitian tindakan kelas bertujuan untuk memperbaiki dan meningkatkan kondisi serta kualitas pembelajaran di kelas dan meningkatkan layanan profesional dalam konteks pembelajaran serta memberikan kesempatan pada guru untuk melakukan pengkajian terhadap kegiatan pembelajaran yang dilakukan. Penelitian ini dilakukan dengan menggunakan desain penelitian dari Kemmis dan Tagart (Sukardi, 2003:2I4).

\section{Desain Penelitian Tindakan}

Berikut tahap-tahap penelitian tindakan kelas model Kemmis dan Mc Taggart:

a. Perencanaan

Pada tahap awal penelitian ini peneliti menjelaskan tentang apa, mengapa, kapan, dimana, oleh siapa dan bagaimana tindakan tersebut akan dilakukan. Pada tahap inilah peneliti harus mengetahui kebutuhan apa terkait pembelajaran di kelas, dan tindakan apa yang harus dilakukan. Peneliti menyusun berbagi perangkat yang berkaitan dengan pembelajaran sesuai dengan tindakan yang akan dilakukan.

b. Pelaksanaan tindakan

Tahap pelaksanaan tindakan merupakan tahapan dimana peneliti melakukan implementasi terhadap tindakan yang telah dirancang, yaitu pembelajaran kooperatif dengan metode Jigsaw. Peneliti mengimplementasikan hasil rancangan sesuai tahapan yang telah ditentukan.

c. Observasi

Observasi merupakan kegiatan yang dilakukan oleh pengamat guna melakukan pengamatan terkait indikator yang nampak, pada penelitian ini khususnya terkait dengan motivasi belajar mahasiswa. Selain ini pada tahapan ini juga mengamati keberlangsungan perkuliahan yang dilakukan dengan metode Jigsaw.

d. Refleksi

Tahapan refleksi merupakan tahapan dimana peneliti melakukan evaluasi terkait pembelajaran yang telah dilakukan. Evaluasi dilakukan guna mengetahui keunggulan serta kekurangan apa saja yang muncul selama proses pembelajaran berlangsung. Peran tahapan ini sangat penting sebab menentukan apakan akan dilakukan perbaikan pada siklus selanjutnya atau tidak

\section{Hasil dan pembahasan}

Pada penelitian ini kondisi awal prestasi dan motivasi belajar mahasiswa masih berada pada kategori "rendah". Melihat kondisi tersebut peneliti melakukan identifikasi masalah dan mengkaji model pembelajaran yang tepat 
guna meningkatkan prestasi dan motivasi belajar mahasiswa AI-2015 PGSD Universitas PGRI Yogyakarta. Setelah melakukan studi dokumen, peneliti memilih model pembelajaran cooperative learning dengan metode jigsaw untuk meningkatkan prestasi dan motivasi belajar mahasiswa. Melalui metode jigsaw mahasiswa diajak untuk berberan aktif dalam kegiatan perkuliahan melalui kelompok yang telah dibentuk. Terdapat dua klasifikasi kelompok dalam metode ini, yang pertama adalah kelompok asal, dimana setiap anggota pada kelompok ini membahas dan mengkaji satu pokok bahasan yang sama. Kelompok selanjutnya adalah kelompok ahli, dimana setiap anggota pada kelompok asal membentuk kolaborasi dengan anggota kelompok asal yang lain untuk membentuk satu kelompok baru yang disebut kelompok ahli. Pada kelompok ahli setiap anggota kelompok menjelaskan pokok bahasannya sesuai pokok bahasan pada kelompok asal. Dengan demikian seluruh mahasiswa dapat berperan aktif dalam memahami materi perkuliahan.

Penggunaan dan pemilihan media yang tepat dapat membantu anggota kelompok dalam menjelaskan pokok bahasan mereka pada kelompok ahli. Pada materi bangun ruang, media 3D menjadi alat yang sangat membantu dalam pemahaman konsep materi bangun ruang sehingga dapat meningkatkan prestasi belajar mahasiswa. Penggunaan metode pembelajaran jigsaw juga memotivasi mahasiswa dalam mencari sumber belajar lain, bertanggung jawab terhadap tugas yang diberikan serta dituntut untuk kreatif menemukan cara yang tepat dalam menyampaikan hasil diskusi.

Model pembelajaran cooperative learning dengan metode jigsaw sangat membantu mahasiswa dalam meningkatkan prestasi belajar dan motivasi belajar mahasiswa. Hal tersebut nampak dengan adanya peningkatan nilai mahasiswa dan skor motivasi mahasiswa. Berikut ini nilai prestasi dan skor motivasi belajar dilihat dari rerata kelas mulai dari kondisi awal hingga akhir siklus II. Nilai rata-rata prestasi dan motivasi belajar:

\begin{tabular}{|c|c|c|c|}
\hline & Kondisi Awal & SIKLUS I & SIKLUS II \\
\hline Prestasi & 36.96 & 57.92 & 74.28 \\
\hline Motivasi & 44.86 & 65.64 & 77.83 \\
\hline
\end{tabular}

Tabel di atas menjelaskan bahwa adanya peningkatan prestasi dan motivasi belajar yang terjadi setelah penggunaan model pembelajaran cooperative learning dengan metode jigsaw untuk materi bangun ruang. Peningkatan yang terjadi dari kondisi awal hingga akhir siklus II tergolog cukup signifikan melihat selisih rerata kelas yang cukup besar.

\section{Simpulan}

Berdasarkan hasil penelitian yang yang telah dilakukan dan pembahasan hasil penelitian yang telah diuraikan, maka diperoleh kesimpulan sebagai berikut:

Pelaksanaan model pembelajaran cooperative learning dengan metode jigsaw untuk meningkatkan prestasi dan motivasi belajar mahasiswa pada mata kuliah matematika 3 materi bangun ruang:

a. Pembagian kelompok asal sesuai dengan bahan kajian pada materi bangun ruang, yaitu kelompok kubus, balok, prisma segi-n, kerucut, limas, bola.

b. Membentuk kelompok ahli yang beranggotakan masing-masing dari kelompok asal.

c. Mahasiswa melakukan diskusi dan menyelesaikan LKM (lembar kerja mahasiswa)

d. Mahasiswa melakuan pretest sebanyak I kali dan posttest sebanyak 2 kali guna mengetahui prestsi belajar mahasiswa

e. Peneliti melakukan observasi selama perkuliahan terkait motivasi belajar mahasiswa.

Prestasi dan motivasi belajar mahasiswa mengalami peningkatan setelah menerapkan model

pembelajaran cooperative learning dengan metode jigsaw pada materi bangun ruang. Hal ini ditunjukan dengan skor rerata kelas yang mengalami peningkatan pada tiap siklusnya. Pada prestasi belajar yang terjadi 36,96 pada kondisi awal, 57,92 pada siklus I dan 74,28 pada siklus II. Sedangkan peningkatan motivasi belajar 44,86 pada kondisi awal, 65,64 pada siklus I, dan 77,33 pada siklus II. 


\section{Referensi}

A.M, Sardiman. (2003). Interaksi dan Motivasi Belajar Mengajar. Jakarta: PT.Raja Grafindo Hamzah, B. Uno. (2008). Teori Motivasi dan Pengukurannya. Jakarta: Bumi Aksara.

Hook, P. \& Vass, A. (2000). Confident clasroom leadership. London: David Fulton Publishers. Isjoni. 2007. Cooperative Learning Efektivitas Pembelajaran Kelompok. Bandung: Alfabeta. Mahmud. 2010. Psikologi Pendidikan. Bandung: Pustaka Setia.

Ngalim Purwanto. (2006). Psikologi Pendidikan. Bandung: Remaja Rosdakarya.

Rusman. 2012. Model - Model Pembelajaran. Depok : PT Raja grafindo Persada.

Sardiman. (2005). Interaksi dan Motivasi Belajar Mengajar. Jakarta: Rajawali Press. - (2007). Interaksi dan Motivasi Belajar Mengajar. Jakarta: PT Raja Grafindo Persada.

Slameto. (2003). Belajar dan Faktor-faktor yang Mempengaruhinya. Jakarta: Rineka Cipta.

Sumadi Suryabrata. (2006). Psikologi Pendidikan. Jakarta: PT Raja Grafindo.

Syaiful Bahri Djamarah. 2008. Psikologi Belajar. Jakarta : Rineka Cipta.

Trianto. (2010). Mengembangkan Model Pembelajaran Tematik, Jakarta: PT Prestasi Pustaka. - (20II). Model Pembelajaran Terpadu Konsep,Strategi Dan Implementasinya Dalam Kurikulum Tingkat Satuan Pendidikan (KTSP), Jakarta : Bumi Aksara.

Winkel,W.S. (2004). Psikologi Belajar. Jakarta: Gramedia Pustaka 